\begin{tabular}{|c|c|c|c|}
\hline \multirow{3}{*}{$\begin{array}{r}\text { Case Reports in } \\
\text { Gastroenterology }\end{array}$} & \multirow{2}{*}{\multicolumn{2}{|c|}{ Case Rep Gastroenterol 2020;14:150-155 }} & \multirow[b]{3}{*}{$\begin{array}{l}\text { Karger } \\
\text { Open'access }\end{array}$} \\
\hline & & & \\
\hline & $\begin{array}{l}\text { DOI: 10.1159/000507015 } \\
\text { Published online: April 8, } 2020\end{array}$ & $\begin{array}{l}\text { ( } 2020 \text { The Author(s) } \\
\text { Published by S. Karger AG, Basel } \\
\text { www.karger.com/crg }\end{array}$ & \\
\hline & $\begin{array}{l}\text { This article is licensed under } \\
\text { International License (CC BY-I } \\
\text { Usage and distribution for comn }\end{array}$ & $\begin{array}{l}\text { nons Attribution-NonCommercial } \\
\text { ger.com/Services/OpenAccessLice } \\
\text { uires written permission. }\end{array}$ & \\
\hline
\end{tabular}

\title{
Colonic Diverticular Bleeding Associated with Bowel Cleansers before Colonoscopy
}

\author{
Kimitoshi Kubo ${ }^{a}$ Noriko Kimurab Soichiro Matsuda ${ }^{a} \quad$ Momoko Tsuda $^{a}$ \\ Mototsugu Kato \\ aDepartment of Gastroenterology, National Hospital Organization, Hakodate National \\ Hospital, Hakodate, Japan; ${ }^{b}$ Department of Pathology, National Hospital Organization, \\ Hakodate National Hospital, Hakodate, Japan
}

\section{Keywords}

Bowel cleansing · Polyethylene glycol · Diverticular bleeding $\cdot$ Colonoscopy

\section{Abstract}

To date, colonic diverticular bleeding associated with bowel cleansers has not been reported, and its endoscopic and pathological features remain largely unclear. We report a case of colonic diverticular bleeding associated with a bowel cleanser $(137 \mathrm{~g}$ of polyethylene glycol $\left[\right.$ [NIflec $\left.{ }^{\circledR}\right]$ ) before colonoscopy (CS). CS revealed colonic diverticular bleeding in the sigmoid colon. To our knowledge, this is the first report describing the endoscopic and pathological features of colonic diverticular bleeding associated with bowel cleansing before CS.

(C) 2020 The Author(s)

Published by S. Karger AG, Basel

\section{Introduction}

Colonoscopy (CS) is commonly performed not only for the diagnosis and treatment of a wide range of symptoms but for screening and surveillance of colorectal tumors. For bowel preparation for CS, several colon cleansers have been developed and are shown to vary in their efficacy, safety, and tolerability profiles [1]. Of these, polyethylene glycol (PEG) is the most commonly used, in that it does not cause fluid exchange through the mucous membrane 
thus limiting fluid and electrolyte disturbances [2]. While Mallory-Weiss syndrome, electrolyte disturbances, and allergic reactions were reported as major adverse events associated with PEG [3], colonic diverticular bleeding associated with bowel cleansers has not been reported to date and its endoscopic and pathological features remain poorly described. We herein report a case of colonic diverticular bleeding associated with bowel cleansers before CS.

\section{Case Report}

Screening CS was performed on a 55-year-old man, which revealed a flat-elevated lesion presenting as a dome-shaped double elevation in the ascending colon (Fig. 1a, b). Magnifying endoscopy with narrow-band imaging showed irregular vessel patterns in the lesion (Fig. 1c). Three weeks later, he was admitted for endoscopic mucosal resection due to endoscopically suspected well differentiated adenocarcinoma. Of note, he had a history of stroke and hypertension and had taken low-dose aspirin (LDA) and eicosapentaenoic acid but no history of NSAID use. Given that $100 \mathrm{~g}$ of magnesium citrate (Magcorol $\mathrm{P}^{\circledR}$ ) previously used for bowel cleansing in this patient led to poor intestinal lavage, this time, he was administered $137 \mathrm{~g}$ of PEG (NIflec ${ }^{\circledR}$ ). Antithrombotic drugs were discontinued on the day of CS. Three hours later, he presented with hematochezia. CS revealed bleeding from multiple sigmoid diverticula (Fig. $2 \mathrm{a}$ ), on which hemostatic clipping was subsequently performed (Fig. 2b). In endoscopic mucosal resection performed after hemostasis, the resected specimen was a $12 \times 10 \mathrm{~mm}$ lesion, which a histological examination confirmed as well-differentiated type (tub1) tubular adenocarcinoma with a negative margin (Fig. 1d). Hematochezia continued for 3 days from the next day for which 2nd endoscopic hemostasis was not feasible, with hemoglobin decreasing from $14.2 \mathrm{~g} / \mathrm{dL}$ to $10.1 \mathrm{~g} / \mathrm{dL}$. CT revealed multiple diverticula in the sigmoid colon (Fig. 2c). Laparoscopic high anterior resection was performed on diverticulum bleeding of the sigmoid colon 3 days after bowel cleansing. The resected specimen revealed multiple sigmoid diverticula with bleeding (Fig. 3a, b). Again, a histological examination showed bleeding in the diverticulum (Fig. 3c) and diverticulitis with severe chronic inflammatory cell infiltration (Fig. 3d). Both cilostazol and eicosapentaenoic acid were restarted 5 days after surgery. The patient's course was uneventful for 6 months after surgery.

\section{Discussion/Conclusion}

Our case has two important clinical implications. First, bowel cleansers can be a trigger for colonic diverticular bleeding, while the endoscopic and pathological features of colonic diverticular bleeding associated with bowel cleansers remain largely unclear with no reports available in the literature.

PEG is the most commonly used of all bowel cleansers, including Magcorol $\mathrm{P}^{\circledR}$ and NIflec ${ }^{\circledR}$. Common adverse events reported to date with PEG include Mallory-Weiss syndrome [4], esophageal perforation [5], electrolyte disturbances [6], allergic reactions [7], and worsening of heart failure [8]. However, perforation of sigmoid diverticulum is also reported with PEG [9] and the prevalence of colorectal diverticula is reported to be $25.8 \%$ in Japan [10]. In addition, the cumulative incidence of colonic diverticular bleeding is reported to be $0.2 \%$ at 1 year, $2.2 \%$ at 5 years, and $9.5 \%$ at 10 years in a cohort study in Japan [11]. Again, colonic diverticular bleeding is shown to be significantly more common in males and elderly patients aged $\geq 60$ 
years [12], and NSAID and LDA have been reported as risk factors [13]. Our patient had a history of LDA use and was ineligible for endoscopic hemostasis and underwent colectomy according to the current guidelines [14].

The second implication of our case is that colonic diverticular bleeding may have resulted from the involvement of diverticulitis. It has been reported that colonic diverticular bleeding results from disruption of the blood vessels that make up the granulation tissue of the ulcer due to diverticulitis or the exposed blood vessels at the bottom of the ulcer [15]. Diverticulitis with severe chronic inflammatory cell infiltration was observed pathologically. Therefore, it was hypothesized in our study that colonic diverticular bleeding may have resulted from diverticulitis associated with bowel cleansers.

To the best of our knowledge, this is the first report describing the endoscopic and pathological features of colonic diverticular bleeding associated with bowel cleansers.

\section{Statement of Ethics}

Written informed consent was obtained from the patient for publication of this case report and any accompanying images.

\section{Disclosure Statement}

The authors have no conflicts of interest to disclose in association with this study.

\section{Funding Sources}

No funding was obtained for this study.

\section{Author Contributions}

K.K., N.K., S.M., M.T. and M.K. carried out and confirmed the diagnosis, provided the details of the case and contributed to the design of the report. K.K. and M.K. drafted the manuscript. All authors have read and approved the final version of the manuscript.

\section{References}

1 Johnson DA, Barkun AN, Cohen LB, Dominitz JA, Kaltenbach T, Martel M, et al.; US Multi-Society Task Force on Colorectal Cancer. Optimizing adequacy of bowel cleansing for colonoscopy: recommendations from the US Multi-Society Task Force on Colorectal Cancer. Am J Gastroenterol. 2014 Oct;109(10):1528-45.

2 Davis GR, Santa Ana CA, Morawski SG, Fordtran JS. Development of a lavage solution associated with minimal water and electrolyte absorption or secretion. Gastroenterology. 1980 May;78(5 Pt 1):991-5.

3 Belsey J, Epstein 0, Heresbach D. Systematic review: adverse event reports for oral sodium phosphate and polyethylene glycol. Aliment Pharmacol Ther. 2009 Jan;29(1):15-28.

4 Raymond PL. Mallory-Weiss tear associated with polyethylene glycol electrolyte lavage solution. Gastrointest Endosc. 1991 May-Jun;37(3):410-1.

5 McBride MA, Vanagunas A. Esophageal perforation associated with polyethylene glycol electrolyte lavage solution. Gastrointest Endosc. 1993 Nov-Dec;39(6):856-7. 
6 Schröppel B, Segerer S, Keuneke C, Cohen CD, Schlöndorff D. Hyponatremic encephalopathy after preparation for colonoscopy. Gastrointest Endosc. 2001 Apr;53(4):527-9.

7 Stollman N, Manten HD. Angioedema from oral polyethylene glycol electrolyte lavage solution. Gastrointest Endosc. 1996 Aug;44(2):209-10.

8 Granberry MC, White LM, Gardner SF. Exacerbation of congestive heart failure after administration of polyethylene glycol-electrolyte lavage solution. Ann Pharmacother. 1995 Dec;29(12):1232-5.

9 Langdon DE. Colonic perforation with volume laxatives. Am J Gastroenterol. 1996 Mar;91(3):622-3.

10 Yamamichi N, Shimamoto T, Takahashi Y, Sakaguchi Y, Kakimoto H, Matsuda R, et al. Trend and risk factors of diverticulosis in Japan: age, gender, and lifestyle/metabolic-related factors may cooperatively affect on the colorectal diverticula formation. PLoS One. 2015 Apr;10(4):e0123688.

11 Niikura R, Nagata N, Shimbo T, Aoki T, Yamada A, Hirata Y, et al. Natural history of bleeding risk in colonic diverticulosis patients: a long-term colonoscopy-based cohort study. Aliment Pharmacol Ther. 2015 May;41(9):888-94.

12 Nagata N, Niikura R, Aoki T, Shimbo T, Itoh T, Goda Y, et al. Increase in colonic diverticulosis and diverticular hemorrhage in an aging society: lessons from a 9-year colonoscopic study of 28,192 patients in Japan. Int J Colorectal Dis. 2014 Mar;29(3):379-85.

13 Yuhara H, Corley DA, Nakahara F, Nakajima T, Koike J, Igarashi M, et al. Aspirin and non-aspirin NSAIDs increase risk of colonic diverticular bleeding: a systematic review and meta-analysis. J Gastroenterol. 2014 Jun;49(6):992-1000.

14 Nagata N, Ishii N, Manabe N, Tomizawa K, Urita Y, Funabiki T, et al. Guidelines for colonic diverticular bleeding and colonic diverticulus: Japan Gastroenterological Association. Digestion. 2019;99 Suppl 1:1-26.

15 Egashira Y, Akutagawa H, Kawakami K. Pathology of diverticular disease of the large intestine [in Japanese]. Shokakinaisikyo. 2018;30:699-708. 


\section{Case Reports in Gastroenterology}

\begin{tabular}{l|l}
\hline Case Rep Gastroenterol 2020;14:150-155 \\
\hline DOI: 10.1159/000507015 & $\begin{array}{l}\text { @ 2020 The Author(s). Published by S. Karger AG, Basel } \\
\text { www.karger.com/crg }\end{array}$ \\
\hline
\end{tabular}
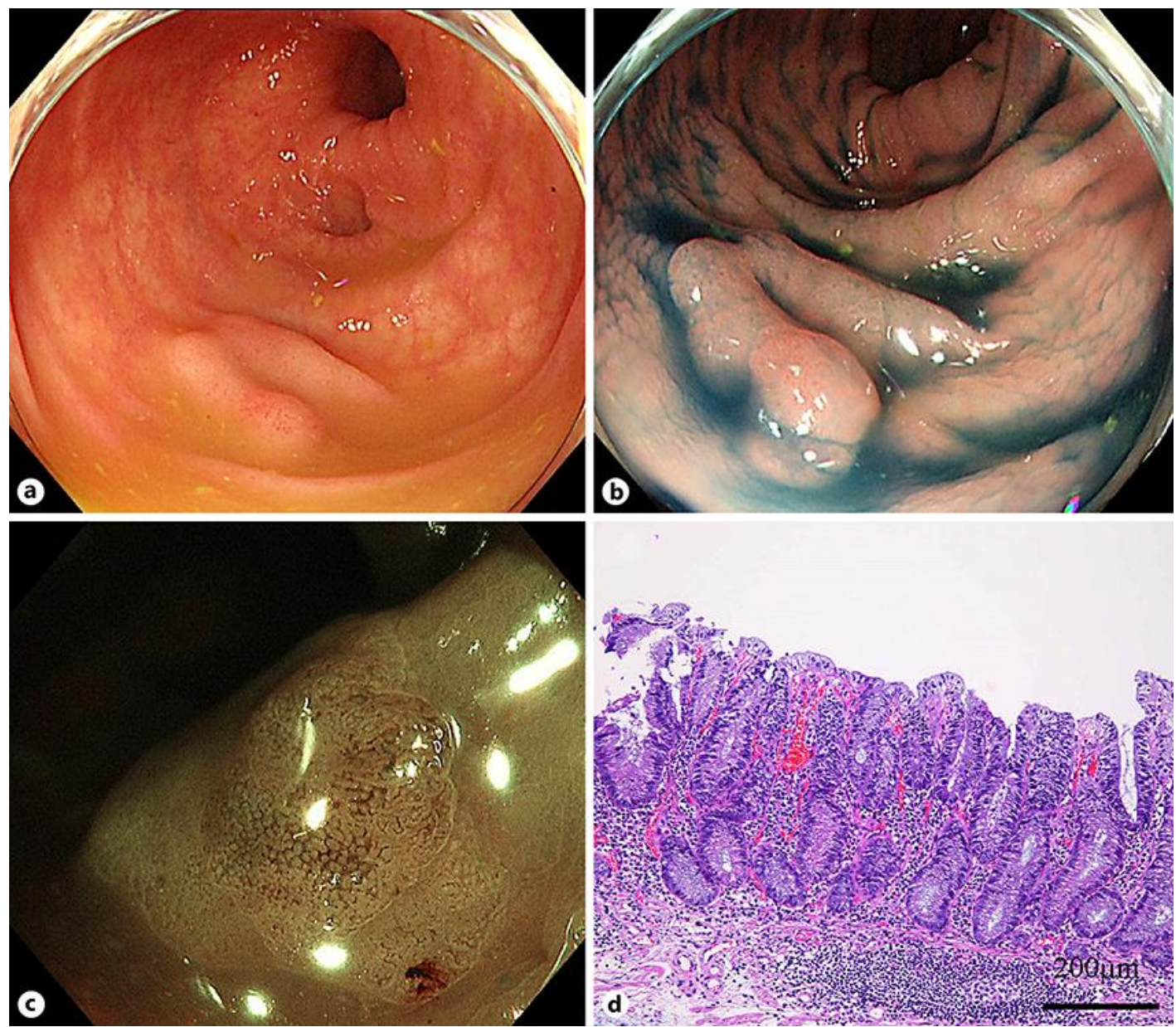

Fig. 1. Colonoscopy. a A flat-elevated lesion presenting as a dome-shaped double elevation in the ascending colon. $\mathbf{b}$ Chromoendoscopy with indigo carmine showing the border of the lesion. $\mathbf{c}$ Narrow-band imaging showed irregular vessel patterns in the lesion. $\mathbf{d}$ A histological examination revealed the lesion to be a welldifferentiated type (tub1) tubular adenocarcinoma (scale bar, $200 \mu \mathrm{m}$ ).
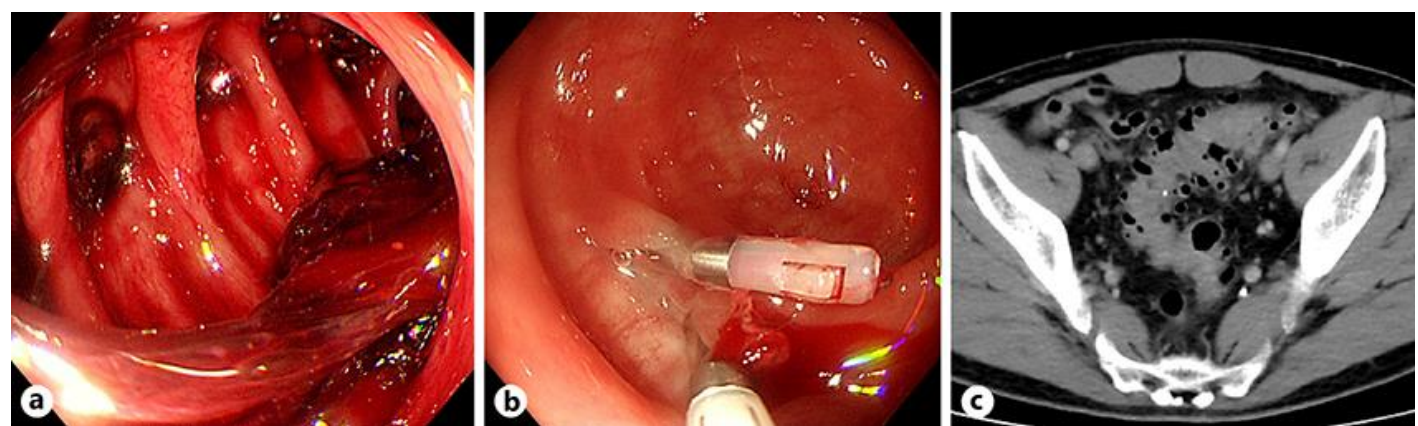

Fig. 2. Colonoscopy and CT. a Multiple diverticula and coagula were observed in the sigmoid colon. b Hemostatic clipping was performed. c CT revealed multiple diverticula in the sigmoid colon. 


\section{Case Reports in Gastroenterology}
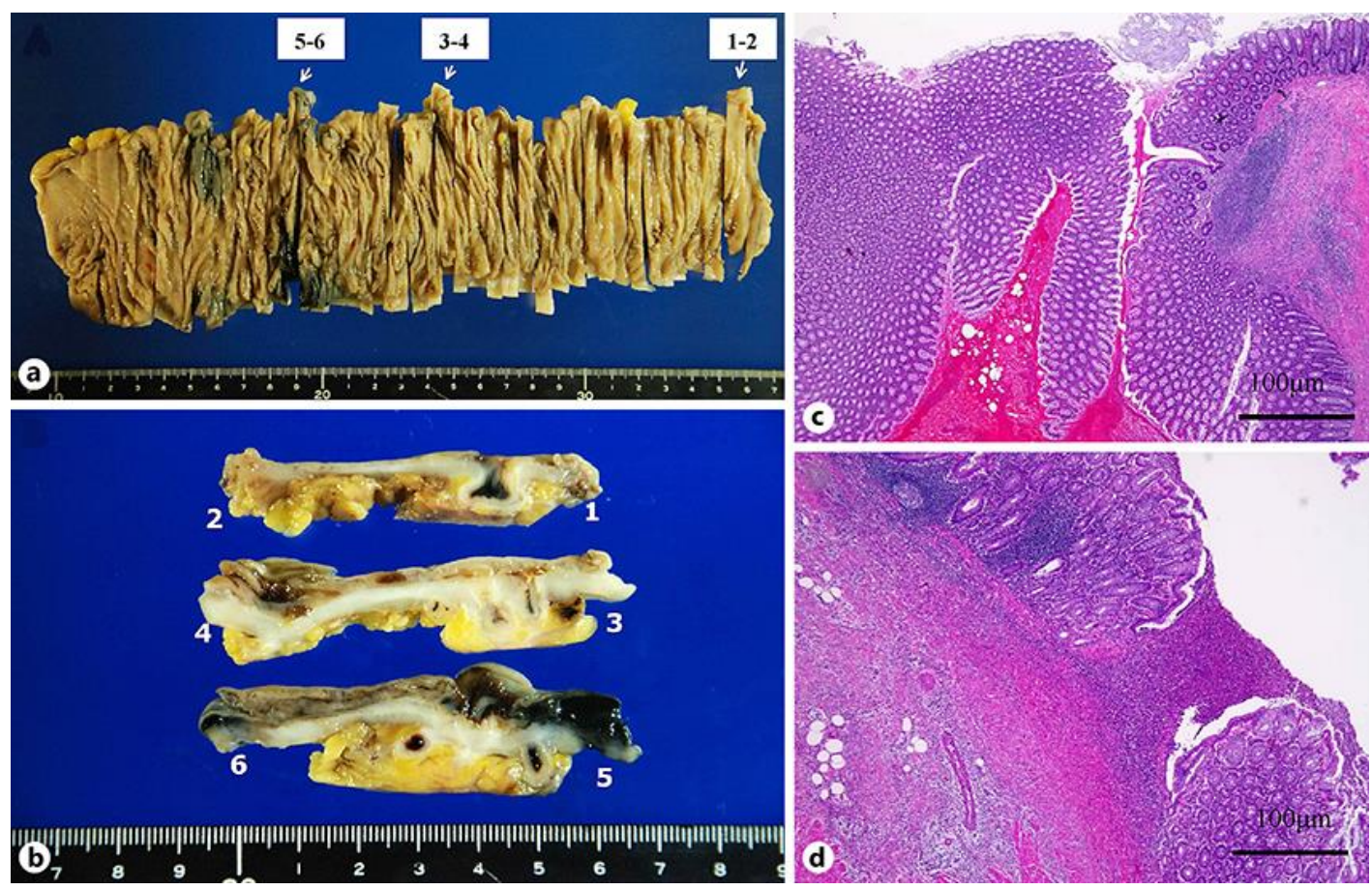

Fig. 3. Resected specimen and histopathologic examination. a Multiple sigmoid diverticula were recognized. $\mathbf{b}$ Bleeding was observed in sections 1-2 and 4-6 of the diverticulum. $\mathbf{c}$ Bleeding was shown to be present in sections 1-2 of the diverticulum (scale bar, $100 \mu \mathrm{m}$ ). $\mathbf{d}$ Diverticulitis with severe chronic inflammatory cell infiltration was shown to be present in sections 3-4 of the diverticulum (scale bar, $100 \mu \mathrm{m}$ ). 